\title{
4
}

\section{The evolution of Cambodian civil society's involvement with victim participation at the Khmer Rouge trials}

Christoph Sperfeldt and Jeudy Oeung

In the scholarly literature on the role of civil society in transitional justice processes there seems to be broad agreement that civil society actors can make important contributions to these processes (Backer 2003; Duthie 2009). However, the scope and nature of civil society's involvement is rarely examined by way of more in-depth case studies. This chapter looks at the case of Cambodian non-governmental organisations' (NGOs) involvement with victim participation at the Extraordinary Chambers in the Court of Cambodia (ECCC) with a view to examining civil society's contributions in more detail.

The ECCC is a hybrid criminal court, combining national and international elements, established in 2003 through an agreement between the United Nations and the Cambodian Government. Based on Cambodia's national law, the ECCC introduced provisions that allow victims of crime to participate in its proceedings as civil parties and thus beyond a role as a witness. Civil parties at the ECCC are considered parties to the proceedings with a range of participatory rights, including the right to request investigations (McGonigle Leyh 2011). It is this aspect of the ECCC's mandate that attracted local NGOs' attention. The influx 
of development aid in the aftermath of the withdrawal of the United Nations Transitional Authority in Cambodia (UNTAC), at the beginning of the 1990s, led to the creation of a comparatively strong and diverse local NGO community in Cambodia (Hughes 2009; Dosch 2012). With the establishment of the ECCC, some of these local NGOs began to develop activities in support of the Khmer Rouge trials.

This chapter takes an evolutionary perspective in that it explores how local civil society engagement with the ECCC's victim participation scheme has changed over time. Internationalised criminal trials often span a long time period. An evolutionary perspective allows capturing over time the dynamic development of different forms of NGO engagement with a formal transitional justice mechanism, such as the ECCC. In doing so, the chapter builds upon and expands arguments, which have been published previously by the authors (Oeung 2016; Sperfeldt 2012a; Sperfeldt 2013a). The focus is here on Cambodian NGOs and their involvement with victim participation at the ECCC, and not on the contributions of the many international NGOs or other Cambodian NGOs' work in related transitional justice areas.

The chapter begins by providing an overview of the four different phases of NGO engagement to date, and examines the various roles that these actors have progressively assumed in supporting and complementing the Court's victim participation scheme. The case of the ECCC is an example of extensive NGO involvement, including in areas of the judicial process that would normally fall within the responsibility of a court. At a point where the ECCC's trial proceedings in its second and largest case are coming to an end, this chapter concludes with a discussion of the opportunities and limitations that come with such wide-ranging NGO involvement. ${ }^{1}$

1 At the time of writing the ECCC is pursuing four cases - often referred to as Case 001, 002, 003 and 004 - but only the first two cases have moved to the trial stage. 


\section{The evolution of Cambodian civil society's involvement with the ECCC's victim participation scheme}

\section{Phase I: Advocacy and early outreach (2003-2007)}

Following the Cambodian Government's request to the United Nations in 1997 for assistance 'in bringing to justice those persons responsible for genocide and crimes against humanity during the rule of the Khmer Rouge from 1975 to $1979^{\prime},{ }^{2}$ it took years to negotiate this agreement and establish a tribunal. Throughout the negotiation process, Cambodian and international civil society organisations advocated for a survivorfriendly tribunal. Once the ECCC started its operations in 2005/2006, discussions began within civil society regarding the future procedural rules of the Court (Acquaviva 2008). Cambodian NGOs showed a keen interest in this process. Members of the Cambodian Human Rights Action Committee (CHRAC), ${ }^{3}$ an umbrella organisation of Cambodian human rights NGOs, suggested that the ECCC's Internal Rules include a mechanism that might address the survivors' suffering, arguing that such provisions would restore survivors' dignity and provide recognition of what happened during the Khmer Rouge period (CHRAC 2005).

Many Cambodian NGOs spoke out in favour of a model where victims could participate as parties civiles, or civil parties - such a model, inspired by the French criminal code, also exists under Cambodian national law. ${ }^{4}$ In May 2006, NGOs met with the Deputy Prime Minister Sok An and ECCC officials, and provided them with a list of recommendations favouring the incorporation of provisions for a civil party system in the ECCC Internal Rules (see Collectif pour les Victims des Khmer Rouges 2006). These NGOs' actions were guided by the belief that 'victim participation will help bridge the gap between the Court and the people and will give victims a voice in this important process' (CHRAC 2006, 7).

2 Letter dated 21 June 1997 from the First and Second Prime Ministers of Cambodia addressed to the Secretary-General, republished in UN doc. A/51/930-S/1997/488 of 24 June 1997, Annex.

3 Established in 1994, CHRAC is coalition of 21 local NGOs working in the fields of human rights, democracy and legal aid in Cambodia.

4 Authors' interview with Hisham Mousar, former project manager of the Khmer Rouge Tribunal Project at the Cambodian NGO ADHOC, Phnom Penh, 1 May 2013. 
On 12 June 2007, the Judges Plenary adopted Internal Rules that made the ECCC the first internationalised criminal court with a victim participation scheme based on the civil party model. ${ }^{5}$

Moreover, these NGOs emphasised the importance of an active role for civil society in any future victim participation process. CHRAC noted that 'Cambodian NGOs are eager to assist the Court' (CHRAC 2006, 9). Similar views were expressed by a number of ECCC officials. David Boyle, who was closely involved in the drafting of the Internal Rules, wrote in 2006, 'active participation by Khmer Rouge victims, aided by NGOs, will constitute one of the essential conditions for impartial and independent trials before the [ECCC]' (emphasis added by the authors) (Boyle 2006, 313). These remarks already foreshadowed the active role NGOs would play in the ECCC's future victim participation scheme.

This account shows that civil society organisations played an instrumental role in advocating for the inclusion of victim participation into the Khmer Rouge trials. Considerations of local ownership and the potential legacy for Cambodia's domestic judiciary led many, but not all, NGOs to speak out in favour of the civil party system. Moreover, the majority of these NGOs were motivated by the firm belief that victim participation could make a positive contribution to social reconstruction, healing and reconciliation among survivors and the Cambodian society at large. ${ }^{6}$

These expectations would remain hollow, however, if Cambodians were unaware of the Khmer Rouge trials. The Open Society Justice Initiative (OSJI) was one of the earliest proponents for comprehensive outreach to local populations. Considering the limited budget of the ECCC and the strength of local civil society, OSJI recommended:

[to] use existing NGOs already operating throughout the country to help with outreach. Existing non-governmental organizations have already established communication mechanisms with the people they serve. Establishing credibility and a positive working relationship with local NGOs will engender more trust with victims and witnesses (OSJI 2004).

5 ECCC Internal Rule 23 states that the purpose of Civil Party action before the ECCC is to (a) participate in criminal proceedings against those responsible for crimes within the jurisdiction of the ECCC by supporting the prosecution; and (b) allow victims to seek collective and moral reparations, as provided in this Rule'.

6 Also at author's interview with Youk Chhang, Director of DC-Cam, 17 May 2013. 
OSJI called therefore on Cambodia's main donors to 'complement ECCC efforts with appropriate initiatives from civil society' (OSJI 2006). By that time, Cambodian NGOs had already started to engage in outreach activities. A 2006 report found that nearly a dozen NGOs had ECCCrelated activities (Penh et al. 2006, 7). Cambodian NGOs, including the Documentation Center of Cambodia (DC-Cam), the Cambodian Association for Human Rights and Development (ADHOC) and CHRAC, had started with radio broadcasts about the Khmer Rouge trials as early as 2002 and further intensified their activities from 2005 onwards. CHRAC added a monthly newsletter in Khmer language with information about the ECCC, while the Center for Social Development (CSD) began to organise public dialogue forums in Cambodia's provinces. These outreach efforts demonstrate the enthusiasm among Cambodian NGOs about the Khmer Rouge trials, as well as the capacity to design new activities and raise funds in support of ECCC-related work. These and subsequent nationwide outreach activities also contributed to increasing awareness among the Cambodian population of the Khmer Rouge trials (Pham et al. 2011a, 21). Through their established relations of trust, NGOs had access to communities that would often be out of reach to official institutions, such as a temporary court. These outreach activities in turn laid the foundation for subsequent victim participation activities. ${ }^{7}$

\section{Phase II: Extensive NGO support - limited ECCC capacity (2007-2009)}

The ECCC struggled to keep pace with the developments during this formative phase. A victim participation process was initially not planned and not budgeted. The Victims Unit (later renamed as the Victims Support Section, VSS) began its operation with limited capacities in January 2008. However, it took almost another two years, and only after receiving earmarked funding from the German Foreign Office, for the unit to be able to operate at a more considerable threshold (ECCC 2008). A new Practice Direction, issued by the ECCC in October 2007, provided a so-called 'Victim Information Form', which survivors interested in participating in the trials had to complete. The complexity of the form combined with the lack of outreach indicated that most survivors, especially those residing in rural areas, would encounter considerable difficulties with filling in and submitting the form.

7 Interviews with Youk Chhang, 17 May 2013, and Leakhena Nou, 30 June 2013. 


\section{Support to the application and participation process}

Against this background, NGOs feared that only a few survivors would be able to participate. Following the announcement of the first indictments at the ECCC in 2007, these NGOs expanded their initial outreach activities to include information about victim participation at the ECCC. Eventually, around a dozen Cambodian NGOs became involved in different aspects of victim participation activities (Sperfeldt 2013a, 348-350). Some of these local NGOs gradually assumed the role of 'intermediaries' between the ECCC and participating survivors. Such intermediary functions related initially to facilitating the application process and communication between the Court and victims.

The first three Cambodian intermediary NGOs that began assisting survivors with the application process from late 2007 onwards, were DCCam, ADHOC and the Khmer Institute of Democracy (KID). After only a few months - by February 2008 - the ECCC's Victims Unit had already received more than 600 applications, providing an indication of the capacity of NGO provincial outreach networks (CHRAC 2008). DC-Cam even set itself the ambitious goal of assisting more than 10,000 survivors in submitting complaints to the ECCC (Kinetz and Yun 2008). These NGOs adapted their existing project structures for the purposes of ECCC-related outreach: DC-Cam undertaking provincial missions from their head office in Phnom Penh; ADHOC making use of its extensive provincial office network; and KID mobilising its provincial volunteer network.

There was no doubt that for many non-legally trained intermediary staff, the process was a steep learning curve. The challenges were particularly acute during the application process, where NGOs struggled with the difficult victim information form. The completeness of forms submitted by NGOs varied greatly, although the quality improved over time. This situation was exacerbated by a lack of guidance from the ECCC, requiring many intermediary NGOs to go back and forth between applicants and the Court to seek supplementary information or further proof of identity. ${ }^{8}$ Yet, through their intermediary role, Cambodian NGOs established important channels of communication between the Court and the participating survivors. In doing so, they helped to bridge the gap between the majority of survivors who reside in rural areas and

8 Interview with Long Panhavuth, 27 May 2013. 
the ECCC. Youk Chhang, Director of DC-Cam, argues that it created a space for the victims to walk through, come to the court ... it creates communication lines with the court. This, to me, can be considered a success'. ${ }^{9}$

In early 2008, the ECCC recognised the first civil parties who now sought legal representation. Following inquiries by civil party applicants and NGOs, the ECCC administration declared that it did not intend to establish a legal aid scheme for civil parties (Kinetz and Prak 2008). In a country where most survivors lacked the means and an appropriate education to follow the proceedings by themselves, this would be a major obstacle to active participation (Thomas and Chy 2009). Local intermediary organisations, fearing that civil parties were not able to exercise their right to participate, reached out to local legal aid NGOs, such as the Cambodian Defenders Project (CDP) and Legal Aid of Cambodia (LAC) (Sperfeldt, Oeung and Hong 2010). These Cambodian lawyers, often in conjunction with international pro bono lawyers, began representing the first civil parties before the ECCC.

These NGOs and individual lawyers used their involvement to direct attention to issues that were initially neglected by the ECCC, including sexual and gender-based violence as well as crimes against minority populations (Nguyen and Sperfeldt 2014). For instance, NGOs were crucial in working with civil party lawyers in getting the ECCC to investigate the crime of forced marriage and include it as part of the indictment (Studzinsky 2012). One of the most innovative non-judicial NGO activities was the so-called 'women's hearing' initiated by the NGO CDP (Ye 2014). Thus, local NGOs and their collaboration with lawyers and survivor groups were essential in complementing the ECCC's investigative activities and painting a more complete historical account of the crimes committed under the Khmer Rouge regime.

Against the background of a growing backlog of unprocessed forms at the Victims Unit, considerable delay in notifying applicants of the status of their applications and the lack of a court-funded legal aid scheme, a number of Cambodian NGOs decided that they needed to bring their engagement to another level. The main concern cited by NGO workers was that many Khmer Rouge survivors would lose out on the opportunity to be part of the ECCC process. Yet coordination among NGOs was difficult

9 Cited from interview with Youk Chhang, 17 May 2013. 
(Oeung 2012, 40). NGOs are by their nature independent organisations, each with their specific goals and approaches. The only systematic effort of coordination among NGOs took place within the CHRAC network and its extended membership. CHRAC's member organisations established a coordinated support scheme for victim participation. ${ }^{10}$ The support scheme consisted of three components: assisting interested survivors with completing and submitting the ECCC Victim Information Form; ${ }^{11}$ sending these forms to the CHRAC Secretariat, as focal point for quality control and coordination; and offering legal representation to unrepresented civil parties, through two legal aid member organisations and in collaboration with international pro bono lawyers (see Figure 4.1). ${ }^{12}$

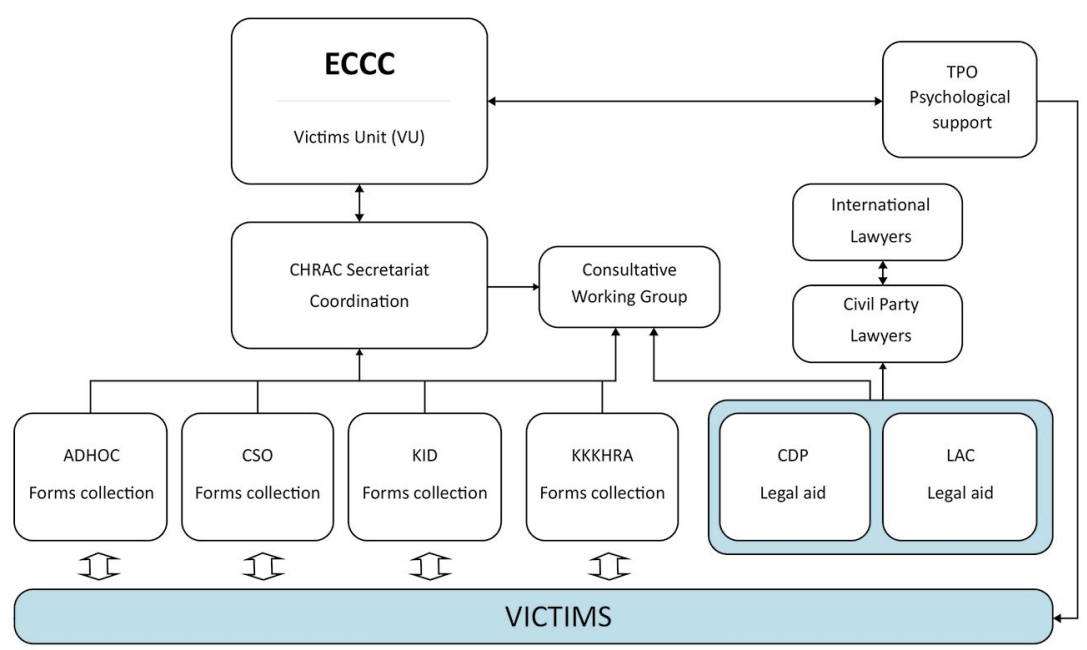

Figure 4.1: Chart of the CHRAC Support Scheme.

Source: Oeung and Sperfeldt (2010).

10 These coordination efforts were influenced positively by the fact that a number of local NGOs engaged in ECCC-related work and received funding through a comprehensive donor support program, implemented by the German Development Service (DED, later merged into GIZ).

11 These NGOs included the Cambodian Human Rights and Development Association (ADHOC), the Khmer Institute of Democracy (KID), the Center for Social Development (CSD, whose responsibilities were later carried on by the Center for Justice and Reconciliation, CJR) and the Khmer Kampuchea Krom Human Rights Association (KKKHRA).

12 The legal aid organisations were the Cambodian Defenders Project (CDP) and Legal Aid of Cambodia (LAC). Two lawyers from each organisation were involved in representing civil parties before the ECCC, often in partnership with various international pro bono lawyers. In addition, CDP lawyers later specialised in representing victims of gender-based violence. The only other NGO providing a continuous presence of two Cambodian lawyers was Avocats Sans Frontiers (ASF) France. 


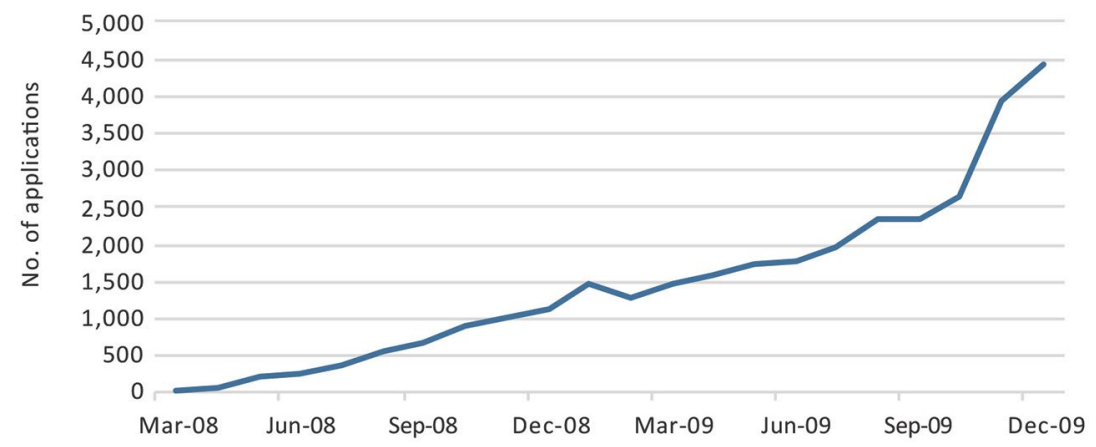

Figure 4.2: Accumulated submissions by CHRAC of ECCC Victim Information Forms.

Source: Oeung and Sperfeldt (2010).

From its inception in March 2008 until the deadline for Case 002 civil party applications in December 2009, more than 4,440 applications were submitted to the VSS through the CHRAC support scheme (see Figure 4.2, Oeung and Sperfeldt 2010). The majority of those applicants were female (63 per cent), and more than 60 per cent applied for civil party status, with the rest submitting general complaints. Based on statistics provided by the VSS, an estimated 60 per cent of all application forms were submitted to the VSS through the CHRAC support scheme and its member organisations.

Data from the VSS confirm the prominent role played by NGOs in facilitating the victim participation process at the ECCC. Of the more than 8,200 victim information forms received by the VSS in Case 002 in total, more than 80 per cent were submitted through NGO intermediaries (ECCC OCIJ 2010, para. 11). Apart from the Cambodiabased intermediaries, outreach among the Cambodian diaspora has also contributed to this achievement. ${ }^{13}$

In response to a perceived lack of ECCC capacities, many intermediary NGOs gradually expanded their involvement with the victim participation process, taking on ever greater responsibilities. Initial straightforward outreach projects developed into more comprehensive victim support programs including activities such as notifying survivors of the status of their applications, facilitating legal representation for civil parties and supporting civil parties with travel and other logistics

13 Interview with Leakhena Nou, Phnom Penh, 30 June 2013. 
(Sperfeldt 2013a, 350-351). These NGOs simply had not anticipated that, after the initial application stage, they would be left to deal with numerous follow-up activities, which they had expected to fall within the responsibility of the Court.

\section{NGOs at their zenith - comprehensive support in Case 001}

The ECCC's first trial in Case 001 against Kaing Guek Eav, alias Duch, proved to be the zenith of NGO support to victim participation. More than 90 civil parties in Case 001 benefited from various forms of NGO assistance ranging from help with their application and visits to the ECCC, to facilitating legal representation and arranging meetings with their lawyers. All civil parties eventually found a legal representative, with little assistance from the Court and mostly through NGO facilitation. These lawyers often worked on a pro bono basis and had no further resources available to meet with their clients. It was left to NGOs to organise regular meetings between lawyers and their clients and to provide support for civil parties and other victims who wished to attend the trial hearings. This presence in the courtroom throughout the trial hearings increased understanding among civil parties of the issues at trial and provided a forum for consultations.

In addition, psychological care through Cambodian mental health workers of the local NGO Transcultural Psychosocial Organization (TPO) assisted in minimising negative side effects from the participation process (Strasser et al. 2011a). As the ECCC did not retain any in-house counselling capacity, it signed a Memorandum of Understanding with TPO, making the NGO responsible for providing mental health services to survivors participating in the Court's proceedings. Working in close cooperation with the VSS and the Witness and Expert Support Unit, TPO counsellors delivered psychological support to approximately 90 civil parties and 31 witnesses during the trial of Case 001 (Strasser et al. 2011b).

Cambodian NGOs' engagement with victim participation in Case 001 showed how far-reaching NGO support can be, as well as the extent to which an internationalised criminal court has ultimately relied on such assistance. The fact that some NGOs assumed roles as intermediaries compensated, to some extent, for the lack of preparedness and services from the ECCC in this phase. In a study conducted among civil parties who testified at the trial in Case 001, 'all of the civil parties said that their 
primary connection to the court was not through the Victims Unit but through their lawyers and local NGOs' (Stover, Balthazard and Koenig 2011, 14).

There is evidence of a correlation between extensive NGO support to victim participation and the attitudes of civil parties to the justice process as a whole. A survey conducted by Pham and colleagues among Cambodian civil parties in Case 001, found that 63 per cent of the respondents felt 'extremely' supported by NGOs during the application process, and 68 per cent received information from NGOs at least once a month (Pham et al. 2011b, 273-277). The authors of this study conclude that 'despite some disappointments in the Duch trial outcomes, civil parties felt positive about their overall participation, suggesting the importance of that process' (Pham et al. 2011b, 284-285). These results highlight the importance of support services to enable a satisfactory participation process.

\section{Phase III: Decrease in NGO capacity - more ECCC activities (2010-2013)}

Prior to the beginning of the ECCC's second trial in Case 002 the balance between NGO and ECCC activities began to shift. A steady decline of NGO support was accompanied by an expansion of capacity at the ECCC. A number of reasons may explain these changes, including (i) a rebalancing in the flow of external donor funding, with further earmarked funding allowing the VSS to expand its activities, while donor funding to NGOs saw a considerable decrease; ${ }^{14}$ (ii) a recognition among ECCC officials that the Court had to deliver some minimal victim support measures in view of the large number of civil parties participating in Case 002, most visibly manifested in the fact that the ECCC now provided a limited legal aid capacity for unrepresented civil parties; and (iii) organisational changes among NGOs, with some organisations ceasing their operations, ${ }^{15}$ accompanied by frustration among intermediaries about the limited progress in enhancing the collaboration between the Court and NGOs.

14 The German Government extended its earmarked funding to the VSS twice, while larger EU-funded projects to ADHOC and KID came to an end, without replacement at a similar level.

15 CSD, and later CJR, and KKKHRA ceased their ECCC-related operations sometime in 2009 and 2010 . 
Paradoxically, this decline in NGO activities occurred in a context of growing needs with almost 4,000 civil parties now requiring support for their participation in Case 002. The major donors to the ECCC showed little far-sightedness when they cut their complementary funding to civil society in the midst of ongoing trials and with little coordination among themselves - eventually donor fatigue prevailed. ${ }^{16}$ In response to these constraints, some NGOs decided to scale back and consolidate their activities. During the trial of Case 002, NGO support was, by and large, limited to two larger intermediaries, ADHOC and DC-Cam, complemented by specialised NGO programs for vulnerable victim groups, such as victims of gender-based violence and those from minorities. ${ }^{17}$

Against these odds, and considering the much larger number of participating victims in Case 002, some NGOs became inventive. ADHOC amended its victim support scheme and devised, in 2010, a countrywide network for the approximately 1,800 civil parties that had applied through the NGO. From among these civil parties, the NGO identified so-called civil party representatives (CPRs), who were directly involved in the communication process. These CPRs benefited from capacity-building and served as focal points in their respective geographic area, where they facilitated communication with ADHOC, the ECCC and lawyers. This network not only empowered survivors by directly involving them in participation activities, it also represented the most comprehensive communication effort with civil parties during the trial phase of Case 002/01, from 2011 to 2014, covering nearly half of all civil parties before the ECCC (Balthazard 2013).

Although Cambodian NGOs supported ECCC victim participation with a high level of good will, care should be taken, however, to avoid underestimating the divergences within the relationship between NGOs and survivors - particularly when NGO representatives claim to speak on behalf of victims. Even though NGOs and survivor groups often share a number of common objectives, they are rarely unified in their opinions

16 The only continuous donor program around the ECCC with a focus on civil society was implemented, since 2007, by the German Development Service's Civil Peace Service Program and later continued under the auspices of the GIZ.

17 CDP was able to expand its support for victims of gender-based violence, while LAC maintained a small support project for Khmer Krom and ethnic Vietnamese minority civil parties. DC-Cam continued to implement a special project for the Cham population. 
and attitudes. Nascent victim associations, such as Ksem Ksan, struggled to find a foothold in Cambodia's competitive civil society sector and were often left to fend for themselves.

Despite the decrease in funding, Cambodian NGOs involved in the ECCC's victim participation scheme continued their advocacy around victims' rights. NGOs organised numerous advocacy events and radio call-in shows. During the phase from 2010 to 2013, many Cambodian NGOs stepped up their advocacy especially regarding the ECCC's collective reparations mandate with the aim of achieving more tangible outcomes for the participating survivors.

\section{Phase IV: NGO engagement with collective reparations (2014-2018)}

The most recent phase saw a further decline in NGO outreach capacities - ADHOC's vital civil party representative scheme ended its operations in 2015, citing a lack of sufficient donor support. Suddenly, half of the civil parties before the ECCC were cut off from their most important platform for information and engagement with the trials. The combined decrease in support to outreach and to non-ECCC Cambodian lawyers, who nominally still represented the majority of civil parties, left many civil parties without the ability to contact their lawyers (Oeung 2016). Sporadic ECCC provincial outreach fora never fully compensated for the waning NGO support. As a result, many civil parties know little about the proceedings in Case 002 (Sperfeldt, Hyde and Balthazard 2016).

While activities that had dominated a decade of NGO involvement with the Khmer Rouge trials were gradually coming to an end, NGO interest in the ECCC's evolving collective reparations scheme was on the rise. Alongside the International Criminal Court (ICC), the ECCC is one of the few internationalised criminal courts with a reparations mandate (Sperfeldt 2012b). The ECCC's Internal Rule 23 limits the scope of reparations in that civil parties are only allowed to seek 'collective and moral reparations', thus excluding individual reparations. In 2010, ECCC judges amended the Internal Rules with a view to providing for more flexibility in designing and implementing collective reparations measures in relation to Case 002 and beyond. The Internal Rules now empower the VSS to identify and design projects, which give effect to the reparations 
awards sought by civil parties. ${ }^{18}$ The rules specifically mention that the VSS can collaborate with NGOs in developing and implementing such projects.

Local NGOs and survivors alike have put much hope in the reparations process, and it is foreseeable that the ECCC will not be able to satisfy all expectations. After a slow start, a number of Cambodian NGOs began working with the VSS to see a few symbolic measures materialise. At the preparatory stages for Case 002, these NGOs provided space for discussions, facilitated input from external stakeholders, and submitted multiple proposals to the Court with the aim of exploring options for the implementation of collective reparations (Sperfeldt and Winodan 2009). Moreover, intermediary NGOs' support was vital for facilitating consultations with civil parties about their preferences for collective reparations measures. The result of these consultations fed into the consolidated reparations request in Case 002, where civil parties requested measures in relation to remembrance and memorialisation, rehabilitation, documentation and education, and a few other projects (Kirchenbauer et al. 2013, 38-44).

From the 13 reparations projects proposed by the civil parties in Case 002/01, 10 projects involved NGOs as implementers and some projects were associated with initiatives from the Cambodian diaspora. External donors contributed more than US $\$ 770,000$ to the 11 reparations projects ultimately recognised by the Trial Chamber in Case 002/01. Both the ECCC and the NGOs benefited from this arrangement: the Court was able to take credit for almost a dozen reparations projects it could never have implemented on its own, and NGOs were able to improve their standing and raise additional funding. The relative 'success' of this scheme meant that more NGOs became involved - further broadening NGO participation in Case 002/02 reparations projects beyond the group of NGOs that had engaged in ECCC-related work over the first decade of the tribunal's existence. Considering the lack of outreach capacities, however, the impact of these reparations initiatives on survivors is less certain.

NGOs' involvement with this type of restorative and rehabilitative work has expanded the possibilities of the ECCC's legacy, especially in the fields of memory culture, documentation and education. For instance, DC-Cam is building a new genocide education and research hub - the

18 ECCC Internal Rules 12bis (2) and (3), and Rule 23quinquies. 
Sleuk Rith Institute - while smaller NGOs, such as Youth for Peace and Kdei Karuna, work with youth and community-based approaches in promoting storytelling, art projects and exhibitions to learn about and remember Khmer Rouge atrocities. Many of these projects have a pilot character and provide valuable lessons for future up-scaling in a postECCC memory and education environment (Oeung 2016, 120).

\section{Harnessing civil society involvement in official transitional justice mechanisms}

By complementing a purely retributive justice process with some restorative justice elements, transitional justice mechanisms like the ECCC have created both new opportunities and challenges for the institutions involved and the participating survivors (McGonigle Leyh 2009). In particular, the participation of a large number of survivors creates demand for a whole range of associated services that may exceed a court's resources or expertise. In some contexts, local civil society may be well positioned to support victim participation and serve some of the many demands of complex participation schemes.

The ECCC provides a case for studying extensive NGO support to victim participation in an official transitional mechanism (Hermann 2010). The observations in this chapter suggest that courts should be encouraged to utilise the comparative advantage of local civil society organisations, including their knowledge of the local context, proximity to target populations and their generally less cost-intensive activities. In relation to the ECCC, Pham and colleagues recommended that 'NGOs who have been the backbone of victim participation should be further supported and recognized in their role as intermediaries between the court and the victims' (Pham et al. 2011b, 285).

Thus, while reaching out to civil society appears advantageous, the observations in this chapter also suggest that such an engagement with actors outside the courts requires a more structured collaborative process. No strategic approach to collaboration developed between the ECCC and intermediary NGOs. ${ }^{19}$ Sporadic meetings between the VSS and intermediary NGOs were only replaced at the beginning of 2010 by more

19 Interviews with Long Panhavuth, 27 May 2013, and Youk Chhang, 17 May 2013. 
regular outreach coordination meetings with the ECCC Public Affairs Section. The Court simply failed to recognise that it would benefit from playing a lead role in coordinating NGO activities of relevance to the implementation of its mandate on victim participation. As a result, the civil party process lacked a joint outreach and victim strategy from the ECCC and civil society (ICTJ 2010, 11-18).

Stover and colleagues therefore suggest that 'it may even behove courts to formalize their relationship with such NGOs and facilitate the creation of an official or unofficial network of local organizations to meet the needs of victim participants' (Stover, Balthazard and Koenig 2011, 43). Courts need to develop a forward-looking approach towards collaboration with civil society and states, lead the planning process and, where necessary, assist with capacity-building. Such an approach to collaboration would ultimately contribute to making victim participation and outreach processes more efficient. In view of increasing workloads with large-scale victim participation and stagnant budgets, it may even be one of the few avenues available to implement a court's mandate in these areas (Sperfeldt 2013b, 1111-1137).

Yet, the evolutionary perspective applied in this chapter has also shown that this will not be possible, if transnational justice donors - domestic or international - do not begin with rebalancing their assistance. This is best illustrated by the fact that only 9 per cent of international assistance to transitional justice in Cambodia between 2002 and 2012 was going to civil society, while the ECCC absorbed US $\$ 250$ million in the same time period - around 91 per cent of that assistance (Arthur and Yakinthou 2015, 6). Thus, even if local NGOs engage in advance planning and offer more coordinated support activities, they ultimately cannot guarantee the continuation and reliability of these services. Such decisions remain in the hands of mostly external donors who have to deal with fiscal uncertainties and often do not display the endurance required by lengthy internationalised criminal justice processes. NGOs' dependency on external funds ultimately proved to be their Achilles heel. It also introduced dynamics that were not always driven by the needs of the victim participation process, but instead by the availability of funds and changing donor priorities.

While many donors question the sustainability of longer-term civil society engagement, they have not shown that sole reliance on state-centric approaches delivers better or locally more relevant outcomes. Diversifying 
transitional justice initiatives among multiple actors in society may assist with spreading risks and opportunities, as well as mobilising greater segments of the population to engage with transitional justice mechanisms and thereby increasing local ownership of their outcomes. Such an approach may produce more positive and sustainable legacies than temporary mechanisms, including internationalised courts, can achieve on their own.

\section{Bibliography}

Acquaviva, Guido. 2008. 'New Paths in International Criminal Justice? The Internal Rules of the Cambodian Extraordinary Chambers'. Journal of International Criminal Justice 6: 129-151. doi.org/10.1093/jicj/mqm085.

Arthur, Paige and Christella Yakinthou. 2015. 'Funding Transitional Justice: A Guide for Supporting Civil Society Engagement'. Public Action Research.

Backer, David. 2003. 'Civil Society and Transitional Justice: Possibilities, Patterns and Prospects'. Journal of Human Rights 2 (3): 297-313. doi.org/10.1080/ 1475483032000132999.

Balthazard, Mychelle. 2013. 'Khmer Rouge Tribunal Project Evaluation Report, 2010-2012'. Consultant report, August 2013.

Boyle, David. 2006. 'The Rights of Victims: Participation, Representation, Protection, Reparation'. Journal of International Criminal Justice 4: 307-313. doi.org/10.1093/jicj/mql006.

CHRAC (Cambodian Human Rights Action Committee). 2005. 'Internal Report about the Delegation Visit to the ECCC'. Copy on file with the authors.

CHRAC. 2006. 'Comments on the ECCC Draft Internal Rules'. Submitted to the 2nd ECCC Plenary, Phnom Penh, 17 November 2006.

CHRAC. 2008. 'CHRAC Workshop on Complaints Procedures'. Workshop held on 22 February 2008 in Phnom Penh. Report prepared by Christoph Sperfeldt and Lach Sreytouch.

Collectif pour les Victims des Khmer Rouges. 2006. 'Propositions Relatives aux Droits des Victimes des Khmer Rouges devant les Chambres Extraordinaires Cambodgienes'. Paris, April 2006.

Dosch, Joern. 2012. 'The Role of Civil Society in Cambodia's Peace-building Process: Have Foreign Donors Made a Difference?'. Asian Survey 52 (6): 1067-1088. doi.org/10.1525/as.2012.52.6.1067. 
Duthie, Roger. 2009. Building Trust and Capacity: Civil Society and Transitional Justice from a Development Perspective. New York: International Center for Transitional Justice.

ECCC (Extraordinary Chambers in the Court of Cambodia). 2008. 'Germany Pledges 1.5 Million Euro to Victim Support Unit'. Media Alert, 26 November 2008.

ECCC OCIJ (Office of the Co-Investigating Judges). 2010. 'Closing Order'. Case 002, D427, 15 September 2010.

Hermann, Johanna. 2010. 'Reaching for Justice: The Participation of Victims at the Extraordinary Chambers in the Courts of Cambodia'. Centre on Human Rights in Conflict Policy Paper No. 5. University of East London, September 2010 .

Hughes, Caroline. 2009. Dependent Communities: Aid and Politics in Cambodia and East Timor. Ithaca: Cornell University Press.

ICTJ (International Center for Transitional Justice). 2010. 'Outreach Strategies in International and Hybrid Courts'. Report of the ICTJ-ECCC Workshop, Phnom Penh, 3-5 March 2010.

Kinetz, Erika and Yun Samean. 2008. 'DC-Cam Team Searching for KR Complainants'. Cambodia Daily, 17 March 2008, 35.

Kinetz, Erika and Prak Chan Thul. 2008. 'ECCC Struggling To Cover Victims' Legal Costs'. Cambodia Daily, 15 February 2008, 1-2.

Kirchenbauer, Nadine, Mychelle Balthazard, Latt Ky, Patrick Vinck and Phuong Pham. 2013. Victim Participation before the Extraordinary Chambers in the Courts of Cambodia: Baseline Study of the Cambodian Human Rights and Development Association's Civil Party Scheme for Case 002. Phnom Penh and Cambridge, MA: Cambodian Human Rights and Development Association and Harvard Humanitarian Initiative, Harvard University.

McGonigle Leyh, Brianne. 2009. 'Two for the Price of One: Attempts by the Extraordinary Chambers in the Courts of Cambodia to Combine Retributive and Restorative Justice Principle'. Leiden Journal of International Law 22: 127-149. doi.org/10.1017/S0922156508005669.

McGonigle Leyh, Brianne. 2011. Procedural Justice? Victim Participation in International Criminal Proceedings. Cambridge/Antwerp: Intersentia. 
Nguyen, Lyma and Christoph Sperfeldt. 2014. 'Victim Participation and Minorities in Internationalised Criminal Trials: Ethnic Vietnamese Civil Parties at the Extraordinary Chambers in the Courts of Cambodia'. Macquarie Law Journal 14: 97-126.

Oeung, Jeudy. 2012. 'Roles of Civil Society in Civil Party Participation: Development toward Victim Participation'. In Conference Report on Hybrid Perspectives on Legacies of the ECCC, edited by Simon Meisenberg, Ignaz Stegmiller and Jeudy Oeung, 39-40. Phnom Penh: ECCC and CHRAC.

Oeung, Jeudy. 2016. 'Expectations, Challenges, and Opportunities of the ECCC'. In The Extraordinary Chambers in the Courts of Cambodia: Assessing their Contributions to International Criminal Law, edited by Simon Meisenberg and Ignaz Stegmiller, 103-121. The Hague: T.M.C. Asser Press. doi.org/10.1007/978-94-6265-105-0_5.

Oeung, Jeudy and Christoph Sperfeldt. 2010. Victim Participation at the Extraordinary Chambers in the Courts of Cambodia: Third CHRAC Monitoring Report. Phnom Penh: Cambodian Human Rights Action Committee.

OSJI (Open Society Justice Initiative) and Working Group on the Extraordinary Chambers. 2004. 'International Standards for the Treatment of Victims and Witnesses in Proceedings before the Extraordinary Chambers in the Courts of Cambodia for the Prosecution of Crimes Committed during the Period of Democratic Kampuchea'. Phnom Penh, May 2004.

OSJI. 2006. 'Memorandum to the Group of Interested States: Priority Issues for the Extraordinary Chambers in the Courts of Cambodia (ECCC)'. Open Society Justice Initiative, October 2006.

Penh, Buntheng, Kimmao Chhouk, Chansokol Men, Sovuthikar Invong and Chea Piseth Ly. 2006. National Reconciliation after the Khmer Rouge. Phnom Penh: Center for Advanced Studies.

Pham, Phuong, Patrick Vinck, Mychelle Balthazard and Sokom Hean. 2011a. After the First Trial: A Population-Based Survey on Knowledge and Perception of Justice and the Extraordinary Chambers in the Courts of Cambodia. Berkeley: Human Rights Center. doi.org/10.2139/ssrn.1860963.

Pham, Phuong, Patrick Vinck, Mychelle Balthazard, Judith Strasser and Chariya Om. 2011b. 'Victim Participation and the Trial of Duch at the Extraordinary Chambers in the Courts of Cambodia'. Journal of Human Rights Practice 3 (3): 264-287. doi.org/10.1093/jhuman/hur022.

Sperfeldt, Christoph and Vinesh Winodan, eds. 2009. Conference Report on Reparations for Victims of the Khmer Rouge Regime. Phnom Penh: CHRAC and ECCC Victims Unit. 
Sperfeldt, Christoph, Oeung Jeudy and Daniel Hong. 2010. 'Legal Aid Services in Cambodia: Report of a Survey among Legal Aid Providers'. Cambodian Human Rights Action Committee, November 2010.

Sperfeldt, Christoph. 2012a. 'Cambodian Civil Society and the Khmer Rouge Tribunal'. International Journal of Transitional Justice 6 (1): 149-160. doi.org/ 10.1093/ijtj/ijr037.

Sperfeldt, Christoph. 2012b. 'Collective Reparations at the Extraordinary Chambers in the Courts of Cambodia'. International Criminal Law Review 12: 457-489. doi.org/10.1163/157181212X648888.

Sperfeldt, Christoph. 2013a. 'The Role of Cambodian Civil Society in the Victim Participation Scheme of the Extraordinary Chambers in the Courts of Cambodia'. In Victims of International Crimes: An Interdisciplinary Discourse, edited by Thorsten Bonacker and Christoph Safferling, 345-372. The Hague: T.M.C. Asser Press. doi.org/10.1007/978-90-6704-912-2_21.

Sperfeldt, Christoph. 2013b. 'From the Margins of Internationalized Criminal Justice. Lessons Learned at the Extraordinary Chambers in the Courts of Cambodia'. Journal of International Criminal Justice 11 (5): 1111-1137. doi.org/10.1093/jicj/mqt069.

Sperfeldt, Christoph, Melanie Hyde and Mychelle Balthazard. 2016. Voices for Reconciliation: Assessing Media Outreach and Survivor Engagement for Case 002 at the Khmer Rouge Trials. Honolulu: East-West Center and WSD HANDA Center for Human Rights and International Justice.

Stover, Eric, Mychelle Balthazard and Alexa Koenig. 2011. 'Confronting Duch: Civil Party Participation at the Extraordinary Chambers in the Courts of Cambodia'. International Review of the Red Cross 93 (882): 1-44. doi.org/ $10.1017 / S 1816383111000439$.

Strasser, Judith, Julian Poluda, Mychelle Balthazard, Chariya Om, Sotheary Yim, Sophea Im, Kok-Thay Eng and Christoph Sperfeldt. 2011a. 'Engaging Communities - Easing the Pain: Outreach and Psychosocial Interventions in the Context of the Khmer Rouge Tribunal'. In We Need the Truth: Enforced Disappearances in Asia, edited by Katharina Lauritsch and Franc Kernjak, 146-159. Guatemala: ECAP.

Strasser, Judith, Julian Poluda, Chhim Sotheara and Phuong Pham. 2011b. 'Justice and Healing at the Khmer Rouge Tribunal: The Psychological Impact of Civil Party Participation'. In Cambodia's Hidden Scars: Trauma Psychology in the Wake of the Khmer Rouge, edited by Beth Van Schaak, Daryn Reicherter and Youk Chhang, 149-171. Phnom Penh: Documentation Center of Cambodia. 
Studzinsky, Silke. 2012. 'Neglected Crimes: The Challenge of Raising Sexual and Gender-Based Crime before the Extraordinary Chambers in the Courts of Cambodia'. In Gender in Transitional Justice, edited by Susanne Buckley-Zistel and R. Stanley, 100-113. Basingstoke: Palgrave Macmillan. doi.org/10.1057/ $9780230348615 \_4$.

Thomas, Sarah and Terith Chy. 2009. 'Including Survivors in the Tribunal Process'. In On Trial: The Khmer Rouge Accountability Process, edited by John D. Ciorciari and Anne Heindel, 214-293. Phnom Penh: Documentation Center of Cambodia.

Ye, Beini. 2014. 'Transitional Justice Through the Cambodian Women's Hearings'. Cambodia Law and Policy Journal 2: 23-38. 
This text is taken from Civil Society and Transitional Justice in Asia and the Pacific, edited by Lia Kent, Joanne Wallis and Claire Cronin, published 2019 by ANU Press, The Australian National University,

Canberra, Australia.

doi.org/10.22459/CSTJAP.2019.04 